\title{
'Defining Paratheatre, From Grotowski to Antiquity’
}

The invention of paratheatre, as a concept applicable to modern performance, stems from the work of Jerzy Grotowski (1933-1999), Polish avant-garde theatre director, best known for pioneering the 'Poor Theatre'. In the 1970s, Grotowski pursued a series of investigations into paratheatre, attempting to change the relationship between spectator and spectacle. This paratheatrical research, iterations of which Grotowski called 'Special Projects', took place primarily in the Polish countryside, but also in other locations, including Pennsylvania. ${ }^{1}$ Participants applied, and were chosen for a certain openness to the experience, which involved living in nature, doing various exercises, some of them ritualistic, and not performing for an audience. A core aim was to free actors from artificiality, including the built environment of the theatre, roles separate from the self, and narrative and plot. $^{2}$ Speaking of Grotowski and the Laboratory Theatre members, Kumiega writes, 'The activity that encapsulated their search (from 19701978) became known in time as paratheatre: formally, this related to an activity that had its roots in drama, but specifically did not result in a theatrical presentation before an audience. The terms "spectator" and "actor" lost their divisive significance, and both the action and the creation became the collective responsibility'. ${ }^{3}$ Grotowski presented the results, which he called 'University of Research', in Wrocław in July of 1975, at the Theatre of Nations Festival. This paratheatrical research continued for a few years after that, and the Laboratory Theatre finally disbanded in 1984.

Grotowski did not coin the word 'paratheatre'. In 1969, presumably without knowledge of Grotowski's work, which was just turning to paratheatre, Theodoros Kretikos described Antigone, performed by the National Theatre, at Epi-

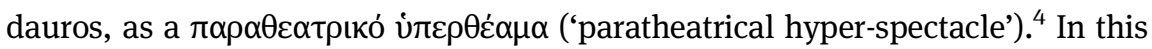

1 Mennen (1975) and Findlay (1980) are first-hand accounts of these 'paratheatrical experiences'. Findlay (1980) reflects on this experience as a 'temporary culture' and a 'third realm - a realm that is neither art on the one hand nor life on the other but rather something else that partakes of both without really being either' (353). Gerould (1980); Schechner (1981; 1985), and Kumiega (1985) provide analysis of Grotowski's paratheatre.

2 On the erasure of the divide between performer and spectator in Grotowski's paratheatre, see esp. Schechner (1981).

3 Kumiega (1985) 144.

4 Van Steen (2002) 208.

Ә Open Access. ( 2021 Mali Skotheim, published by De Gruyter. (cc) BY This work is licensed under the Creative Commons Attribution 4.0 International License. 
usage, the term was derogatory, classifying the 1969 Antigone as less than true theatre. However, Grotowski's lasting influence on paratheatre was to view this as a distinct type of performance, a genre in and of itself, a different way of engaging with and even conceiving of performance and the theatre.

Forty years after Grotowski's paratheatrical experiments, paratheatre lacks a foundational study or theoretical approach equivalent to Abel's 1963 Metatheatre, and is plagued by a persistent confusion about what it is, what types of performance paratheatre might encompass, and how and why paratheatre might be different from traditional theatrical genres. Bruce Wilshire's 1990 essay, 'The Concept of the Paratheatrical,' does not address this, as it mainly considers 'paratheatre' as a metaphor of the theatre applicable to non-theatre contexts such as the performance of social roles, rather than paratheatre as a performance category in itself. ${ }^{5}$ Neither 'paratheatre' nor 'paratheatrical' is in the Oxford English Dictionary, an unfortunate contributing factor to the inconsistent application of these terms to diverse phenomena.

A survey of the use of the term 'paratheatre' in scholarship reveals that it is already being used to designate more informal or low-brow forms of performance, such as puppetry, trick magic, mime, burlesque, and the circus arts, across a wide range of historical eras and geographical regions. In ancient Mediterranean studies, Sifakis uses 'paratheatrical performances' to refer to popular performances which respond to the theatrical tradition, such as those of ancient pantomimes, who told the mythological stories of tragedy in dance, and the Homeristai, who acted out Homeric stories with slapstick humor. ${ }^{6}$ Lin demonstrates that 'popular festive performance' in early modern England included 'various kinds of theatrical and paratheatrical activity' without clarifying what the distinction between the two categories would have been at that time. ${ }^{7}$ Brown describes performances of puppetry, animal baiting, and other entertainments of the fair within Ben Jonson's Bartholomew Fair (1614) as 'paratheatrical spectacles'. ${ }^{8}$ Similarly, Burt writes, in reference to the same period of London theatre history, 'By the late 1620s paratheatrical shows, entertainments, and exhibitions such as prize fighting, fencing, acrobatics, and displays of halberd and pikes, among others, displaced plays as forms of entertainment at theatres like the

5 Wilshire (1990). Oddly, despite publishing his work in The Drama Review, which had published extensively on Grotowski, Wilshire does not mention Grotowski's paratheatre at all in the essay.

6 Sifakis (1992) 140-141. On pantomime, see Paillard's chapter in this volume.

7 Lin (2009) 271-272.

8 Brown (2012) 156. 
Swan, the Rose, and the Hope'. ${ }^{9}$ For Shershow, the 'para-theatrical entertainers' of $17^{\text {th }}$ century London include itinerant puppeteers and other street performers. ${ }^{10}$ On late $18^{\text {th }}$ century Madrid, Espinosa uses 'paratheatrical shows' to refer to 'the heterogeneous variety of popular entertainments - cribs, puppets, magic lanterns, shadow plays, automatons, totilimundis, scientific, and pseudo-scientific experiments, circus performances and dioramas'. ${ }^{11}$

'Paratheatre' is, alternatively, used to indicate activities, including rituals, relating to the theatre, outside of the performance of drama. For example, in a discussion of the relationship between ritual and theatre in ancient Greece, Tzanetou notes that in the Greek context, theatre was ritual, and, 'Religious rituals ... often included events of a theatrical or paratheatrical nature'. ${ }^{12}$ Shared elements of religious rituals and the theatre included 'choral dancing, use of masks, various disguises and role-playing'. ${ }^{13}$ In this usage, paratheatre means those rituals which happen outside of the immediate context of the theatre, but which nevertheless respond to or reference rituals and practices represented in theatrical productions. Wilson suggests that announcements which took place before the start of the tragic competitions at the Athenian Dionysia were 'the most significant focus of collective, para-theatrical attention within the festival programme, ${ }^{14}$ and that even business meetings which occurred after the festival could be viewed as 'para-theatrical social spectacle'. 15

Despite the adoption of the word 'paratheatre', scholars of the premodern theatre may be unaware of the history of this term in the modern theatre, particularly in the work of Grotowski. Rosenmeyer, for example, briefly suggests that Abel might have been more correct to use paratheatre to describe the phenomenon he termed metatheatre, without reference to the contemporary usage of this term in theatre studies. ${ }^{16}$ In contemporary theatre studies, on the other hand, where Grotowski's influence is understood, paratheatre has been used to refer to non-representational performance. Writing on the Catalan poet and playwright Joan Brossa (1919-1998), George calls the use of carnivalesque elements,

\section{Burt (1987) 545.}

10 Shershow (1994) 188.

11 Espinosa (1998) 225.

12 Tzanetou (2002) 338.

13 Ibid.

14 Wilson, P. (2009) 16.

15 Wilson, P. (2011) 84 n. 28.

16 Rosenmeyer (2002) 91. See also Bierl in this volume. 
inspired by the commedia dell'arte tradition, 'paratheatrical devices which belong to an essentially non-representational form of art' ${ }^{17}$

But what does Grotowski's paratheatre have to do with ancient performance? Grotowski did not have ancient Greek performance categories in mind, nor should Grotowski's paratheatrical methods and purposes be confused with those of the ancient theatre. Yet Grotowski's term, 'paratheatre', can be usefully applied to premodern performance categories, including those of the ancient Greek theatre. 'Paratheatre' implies a relationship to the traditional theatrical performance genres, such as tragedy and comedy (and potentially also music), while delineating some separation. It allows scholars of ancient performance to speak of multiple paratheatrical genres as related to one another, under a common umbrella term. This term, 'paratheatre,' or 'paratheatrical entertainment,' has a further benefit, in that it cannot be confused for a specific type of entertainment, in contrast to the term 'juggler,' used in older texts and translations of ancient works to describe a range of types of performers. This causes confusion, as 'juggler' in English has the connotation of one who throws objects up in the air and catches them, as opposed to the medieval French jongleur, who did not only juggle objects, but also performed magic tricks, dances, songs, stories, acrobatics, and jests. ${ }^{18}$ There may have been a time when 'juggler' was an intelligible term in English to describe an ancient mime, pantomime, acrobat, jester, and so on, but this is no longer the case.

Understanding the use of 'paratheatre' in the contemporary theatre is also important, not only because it is part of the history and usage of the word, but also because theatre practitioners experimenting with paratheatre have asked, and continue to ask, questions about what is distinct or unique about paratheatre, for example, in terms of performer-spectator relationship, or the relationship of paratheatre to ritual, which are worthwhile questions to ask of ancient Greek paratheatre as well, even if the answers may be quite different. Just as Thumiger has argued for the existence of multiple metatheatres in ancient and modern contexts, it may be necessary to speak of multiple 'paratheatres,' or in other words, to recognize that paratheatrical performance categories have cultural and historical specificity. ${ }^{19}$

What, then, characterized Grotowski's paratheatre? One important aspect was flexibility of place, as Grotowski's paratheatre took place outside of traditional theatre spaces, in natural settings. This can be related to other theatrical

17 George (1995) 346.

18 For a comprehensive history of the art of the jongleur, see Ziolkowski (2018).

19 Thumiger (2009). 
experiments in the early 1970s which utilized landscape in an attempt to dissolve the boundaries between spectators and performers. Peter Schumann's Bread and Puppet Theatre event, 'Domestic Resurrection Circus,' based in Plainsfield, Vermont from 1970-1974, and in Glover, Vermont from 1975 onwards, is one such example. ${ }^{20}$ Staged as a sort of outdoor fair, performances included puppetry, mime, masked shows, and pageantry. Like Grotowski, Schumann and the Bread and Puppet Theatre rejected the physical space of the theatre for their performances. Communal living on the part of the performers was a key element in both projects. ${ }^{21}$ Above all, both sought a new kind of participation in performance, in which spectators were not separate from performers. ${ }^{22}$

Another aspect of Grotowski's paratheatre was its complex relationship to ritual. On the one hand, many of the activities in the "paratheatrical experiences,' such as running in the woods and dancing around fires, derived from initiation rituals. ${ }^{23}$ Yet, Schechner writes, there was no attempt to reintegrate participants' paratheatrical experiences with their post-Grotowskian lives. Schechner writes that, 'Theatre has but two stances in relationship to society at large: either to be tightly woven into broader social patterns, as rituals are, or to serve as an analytical and dialectical instrument for a critique of society, as Brecht's theatre tried to be'. ${ }^{24}$ Grotowski's 'paratheatrical experiences,' Schechner argues, conformed to neither of these patterns.

The influence of Grotowski's paratheatrical phase on contemporary experimental theatre is also relevant to the development of the meaning of 'paratheatre'. For example, in their 'Paratheatric Rehearsal Technique,' the Gorilla Theatre has adopted Grotowski's paratheatrical approach, using the natural environment and improvisational techniques to break down barriers between spectator and performer. ${ }^{25}$ Antero Alli's ParaTheatrical ReSearch in California and Oregon, and Matt Mitler's Theatre Group Dzieci in New York also build upon Grotowski’s paratheatrical experiments.

Both Alli's ParaTheatrical ReSearch and Mitler's Theatre Group Dzieci have incorporated genres traditionally seen as on the fringes of the theatre, such as fooling, clowning, and puppetry. Antero Alli trained as a mime before adopting Grotowski's paratheatrical methods and developing his own experimental theatre in the 1970s. A desire to break free of social norms, and even social interaction,

\footnotetext{
20 Falk (1977).

21 Falk (1977) 26.

22 Falk (1977) 27.

23 Schechner (1985) 105; Mennen (1975) 67 is an account of one such 'trip to the woods'.

24 Schechner (1985) 106.

25 Sanderson (2013).
} 
and the adoption of ritual actions and body-oriented processes are central to Alli's paratheatrical work. Like Grotowski, Alli favors natural settings without audiences for the experiments. The elimination of the separation between performer and spectator, and the adoption of non-representational forms, is directed, at least in part, at self-realization on the part of the performer. In his manifesto on paratheatre, Alli asserts about the co-development of theatre and paratheatre, 'Any theatre that cannot outgrow itself ceases to function as a vital sustaining ritual. For theatre to remain vital, a kind of 'paratheatre' must be implemented to dismantle stagnant habits that frustrate more truthful creative response. Paratheatre, in the theatre but not of it, must provide a time and space set apart to explore a non-performance setting to excavate the internal landscape towards a total recalibration of performer' ${ }^{26}$

Grotowski and his continuators have drawn upon premodern folk culture and ritual in their explorations of paratheatre. Theatre Group Dzieci, for example, draws upon the premodern and early modern tradition of the Fool to create Fool's Mass, in which fools take over a village mass after the death of the pastor, performed since $1998,{ }^{27}$ and Fool's Wedding, a real wedding orchestrated by the Fools, with Mitler as minister, which took place in New York in $2016 .^{28}$ Fool's Mass incorporates religious songs from the 8 th to the $14^{\text {th }}$ century, collapsing performance and reality through the use of ritual grounded in historical practice, on the one hand, and the character of the Fool, a staple of medieval and early modern performance, who circulated among banqueters at court, performing mockery without a fourth wall. This construction of paratheatre as not just premodern, but specifically medieval, and as such, an antidote to modernity, must be understood in relation to the construction of the ancient Greek theatre as anticipating modernity, as for example in the work of Isadora Duncan. Yet, the world of the ancient Greek theatre, and performance culture more generally, also encompassed genres such as clowning and jesting, as explored in the next section, which may complicate perceived divisions between ancient and medieval performance.

26 Alli (2019).

27 Dzieci Theatre (2019).

28 Tate (2016). 


\section{Paratheatre in Ancient Greece: paramisthomata, akroamata, theamata, thaumatopoiia}

I propose 'paratheatre' or 'paratheatrical entertainment' to mean any genres which were performed by the thaumatopoioi ('marvel-makers'). It is clear from the Greek term thaumatopoiia that there existed a category of performance which was considered to be distinct from the performance of theatrical categories which were eligible for prizes at festivals, such as tragedy, comedy, satyr drama, kitharoidia, and auloidia, for example, necessitating a term in English which might encapsulate this category. Thaumatopoiia cannot be considered exclusively a 'theatrical' performance category, in the sense of a performance within the space of the theatre, as these performances took place in a number of different contexts, including in the theatre, in the street, and at dinner-parties.

Paratheatrical entertainment is also referred to in Greek as akroamata and theamata, 'pleasures for ear and eye'. ${ }^{29}$ This included puppeteering, whose practitioners were called neurospastai, performances of illusion (magic tricks, pebble tricks), funny and parodical performances (jesting, joking, clowning, mime), acrobatics, dance (including pantomime), and perhaps also automata. ${ }^{30}$ Most of these paratheatrical performances were humorous, with the notable exception of pantomime, the tragic dance.

One important venue for paratheatrical entertainment was in public theatres, in the context of festivals. An inscription from Delos from $169 \mathrm{BC}$ includes thaumatopoioi, among them a dancer and puppeteers, at the end of a list of victors from the Delian festival. ${ }^{31}$ In AD 127, in Oenoanda, in Northern Lycia, three days of the month-long local festival, the Demostheneia, were set aside for 'hired performances ( $\pi \alpha \rho \alpha \mu \sigma \theta \omega \dot{\mu} \alpha \tau \alpha)$, among which will be mimes and performances for

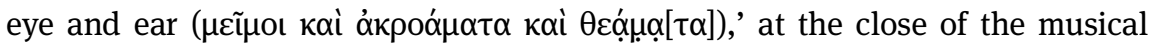
and dramatic competitions and before the athletic competitions. ${ }^{32}$ This document makes clear a fundamental distinction between dramatic and musical genres,

29 For akroamata and theamata used for paratheatrical entertainment, see Plutarch, Moralia 711a; Cassius Dio, Roman History 52.30; Xenophon, Symposium 2.1. It is also common in epigraphy. Milanezi (2004) has explained the terminology relating to thaumatopoia, including akroamata and theamata, and has provided an account of the ancient sources of such terms.

30 Milanezi (2004) 187-195 discusses the categories of the thaumatopoioi, focusing particularly on the humorous arts.

31 IG XI.2 133.

32 SEG 38.1462. For a detailed discussion of this inscription and its context see Wörrle (1988) and the lengthy review, with English translation of the inscription, by Mitchell, S. (1990). 
which were performed in competition, and those who were paid to perform, even though both categories were part of the festival and performed in the theatre.

In addition to public theatres, performance contexts included symposia and the street. Jesters and clowns (planoi and gelotopoioi) were particularly associated with sympotic entertainment. ${ }^{33}$ Performances in the theatre were a significant step up from the more informal marketplace shows, for which crowds circled around the óx $\lambda \alpha y \omega y o$ i ('crowd-gatherers'). ${ }^{34}$ Stobaeus mentions the marketplace and the theatre as the two places where thaumatopoioi performed. ${ }^{35}$ Athenaeus tells a story about a $4^{\text {th }}$ century BC mime, Ischomachus, making this transition from marketplace entertainer, performing to people standing around him, to the

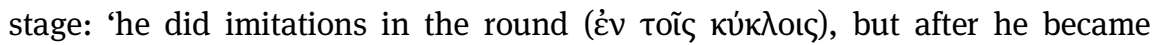

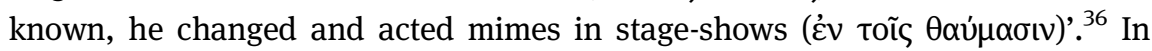
many cases, the same people may have performed in multiple types of venues. One example of such a public-private crossover is the story that performers from the Anthesteria (festival of the pots) in Athens performed at the wedding feast of Caranus in Macedonia ( $4^{\text {th }}$ c. BC), followed by dancers, clowns, and fire-breathing acrobats. ${ }^{37}$ Just as these performers brought something of the prestige of their festival performance to Caranus' wedding, perhaps also paratheatrical entertainment could bring some taste of private performance onto the public stage.

Some paratheatrical performances, such as trick magic, brought a more intimate viewing experience into the theatre. Magic tricks were performed in public, including in the theatre, as well as in private, at symposia. One papyrus from the 2nd or 3rd century $\mathrm{AD}$, concerning the accounting for an athletic festival, mentions a $\mu \alpha y \gamma \alpha v \alpha \dot{\rho}$ sos (conjurer) along with an aulete, mime, and dancer

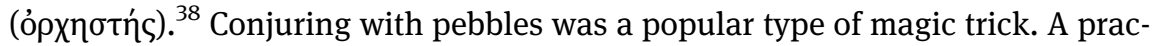
titioner of these pebble tricks was called a $\psi \eta \varphi \tilde{\alpha} \varsigma, ~ \psi \eta \varphi о к \lambda \varepsilon \dot{\pi} \tau \eta \varsigma, ~ \psi \eta \varphi о \lambda o ́ y o \varsigma$,

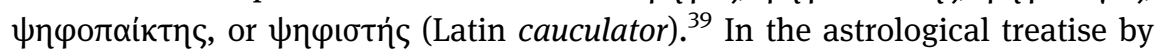

33 See Milanezi (2004) 196-199 for the sympotic context of the shows of these humorists.

34 See Dickie (2001) 602 for discussion of these marketplace entertainments.

35 Stob. 4.50c.95, 'And just like on the stage or some market-place in which the marvel-makers



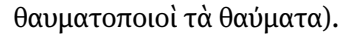

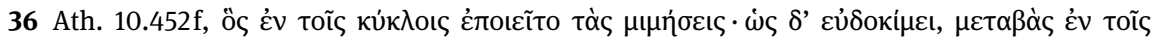



37 Ath. 4.129d, quoting a letter of Hippolochus of Macedonia, a contemporary of Duris of Samos (340-260 BC).

38 P.Oxy. 1050.


juggler to 'someone who tricks spectators, by sleight of hand, into believing that they are seeing what they are not seeing; that is to say, a conjuror or prestidigitator' (600). 
Ps.-Manetho, pebble-conjurers are wandering players, compared to buzzing bees, traveling the earth and living off of the offerings of the crowd. ${ }^{40}$ In addition to informal marketplace shows, pebble-conjurors performed in theatres: according to Athenaeus, the citizens of Hestiaea or Oreos [in Euboea] erected a statue of the



A letter of Alciphron also contains valuable evidence for the practicalities of performance of pebble-conjuring in the theatre. ${ }^{42}$ This fictional letter is in the voice of a farmer who has come to the city to sell his wares. He comes to the theatre and sees various shows. One of them is a pebble-conjurer, who performs his tricks first on a table, and then by interacting directly with the spectators, pulling pebbles from their noses and ears. The farmer emphasizes the smallness of the conjuror's props. Both the cups and the pebbles are small things, suggesting that spectators needed to be close up to see them.

The practice of performing tricks visible only to audience members in the front rows has ramifications for our understanding of the performance of other paratheatrical entertainment which required a close-up view on the part of the spectators. Writing in the $4^{\text {th }}$ c. AD, Gregory of Nyssa also describes a festival of Zeus, at which the crowd ( $\tau$ ò $\pi \lambda \tilde{n} \theta$ oఢ) is so eager to see the 'performances for

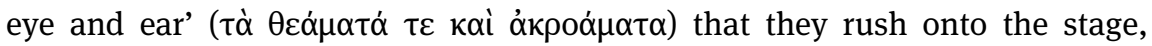
which prevents the thaumatopoioi from performing. ${ }^{43}$ Puppet shows and, if they were displayed in the theatre, automata, would have been visible only to the front rows. While the front rows were occupied by local elites during the festival competitions, it is the common people (Alciphron's farmer, Gregory's tò $\pi \lambda \tilde{\eta} \theta$ os) who are represented as the spectators of paratheatrical entertainment. This either means that there is a disconnect between actual practice (i. e. that elites sitting in the front rows did have a better view of the conjurers and puppeteers) and literary representation, or that the seating during paratheatrical shows was more flexible, allowing spectators who had been sitting farther up to come closer to watch the more intimate performances. The limitations of putting shows on stage which could not be seen clearly by most of the theatre audience may help to explain why trick magic and puppeteering never became festival competitions. Mime, pantomime, and acrobatic performances could be seen from any part of the

40 Ps-Manetho 4.448-449.

41 Ath. 1.19b. Cf. Dickie (2001) 602.

42 Alciphron, Letters 2.17.

43 Gregory of Nyssa, Life of Gregory Thaumatourgos 956b. 
theatre, and it is perhaps not coincidental that these were the performances which eventually made the leap from hired entertainment to festival competitions. ${ }^{44}$

In the theatre, the primary distinction between thaumatopoiia and the musikoi agones was the fact that thaumatopoioi were paid to perform, while actors and poets of tragedy, comedy, and satyr drama, as well as musicians, competed for prizes at the festivals. This line was blurred in the Roman imperial period, when pantomimes were awarded prizes at some festivals, first at the Sebastea in Naples in the first century AD, and at festivals in the Greek East in the late second century AD. ${ }^{45}$ However, even prize-winning pantomimes remained thaumatopoioi, preserving an echo of the earlier hierarchy between prize-winning and hired performance categories.

Throughout this multiplicity of performance contexts, thaumatopoiia did have a persistent relationship to the theatre, and to the 'higher' or more canonical genres performed in the theatre, such as drama. For this reason, thaumatopoiia was 'paratheatrical'. In the case of mime and pantomime, this relationship is very clear. Mime represented scenes set in the real world as opposed to the world of myth, and mimes performed in groups, without masks. In addition to being representational performance, like drama, even intertextual relationships between mime and drama were possible. The Charition (P.Oxy 413), a mime script from Oxyrhynchus from the second century AD, is a spoof of Euripides' Iphigeneia among the Taurians, transposing the Euripidean plot to the Malabar coast of India, with a chorus of Indian men and a chorus of Indian women. ${ }^{46}$ Pantomime dance, on the other hand, was masked, like tragedy, and drew upon the world of myth for its plots. Lucian's extended comparison between tragedy and pantomime in On the Dance suggests that pantomime was considered danced tragedy, each telling the same stories, and acting the same characters, with different methods. ${ }^{47}$

44 The evidence for acrobatic competitions is limited. An epitaph for an acrobat from Beroia from the second century AD refers to prizes ( $\dot{\alpha} \theta \lambda \hat{n} \mu \alpha \tau \alpha)$ and suggests that he competed along-

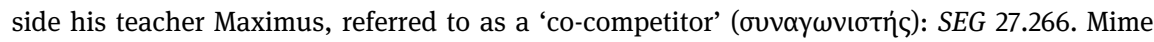
competitions are better attested in the second and third centuries AD: IGSK Ephesos 1135 (victories of the mime Tiberius Claudius Philologos Theseus); LW 1652b (Tralles, honors for the biologos, or mime, Flavius Alexandros Oxeidas, who won at contests in Asia 18 times and Lycia and Pamphylia 26 times). On mime, see Paillard and Duncan in this volume.

45 Slater, W. (1995) discusses the epigraphical evidence for the festival victories of pantomimes. 46 For discussion of this mime and its imperial context, see Hall (2010) and Tsitsiridis (2011). On the Charition, see also Duncan's chapter in this volume.

47 Jory (2004) explores the close relationship between pantomime and tragedy. For an extended study of Luc. Salt., see Lada-Richards (2007). 
As miniature theatre, puppetry also had strong associations with drama. For example, the Athenian claims in Plato's Laws that if children judged the

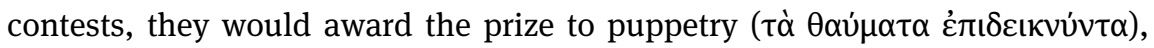
while older children would give the prize to comedy, women and teenagers to tragedy, and old men to rhapsody. ${ }^{48}$ This sets puppetry in a clear relationship to drama, through a hierarchy based on the supposed maturity of its most eager spectators. Small children, he suggests, would award a prize to a category which did not, in reality, have a prize attached to it, but which some spectators may have encountered in the theatre. One of the implications of this passage is that children, as they grow up and learn correct behavior at the festivals, through experience, come to understand that puppetry is not an appropriate prize category. While both exist within the space of the festival, the ability to distinguish between thaumata and drama is one marker of maturity and education for Athenians.

Another form of miniature theatre was the automaton. In the first century BC, Heron of Alexandria, in his treatise on automata, Peri automatapoietikes, describes an automatic theatre in which a five-act tragedy can be viewed, ending in a deus ex machina. Earlier in the treatise, he says that the ancients called those who made such devices thaumatourgoi, because of the amazement of the onlookers. ${ }^{49}$ While it cannot be demonstrated that automata were displayed in the theatre, the text of Heron suggests at least a reference to the contemporary theatre in this automaton.

\section{Conclusion}

Paratheatre in ancient Greece represents a set of performance genres, known collectively in Greek as thaumatopoiia, which were related by a common aesthetic of thauma, and often distinguished, in some way, from genres of festival competition in the theatre. We can see something of Grotowski's experimentation and boundary-pushing in ancient paratheatre, particularly regarding the relationship between performer and spectator. Some paratheatrical entertainers shared a common performance context, the public stage, with the practitioners of tragedy and comedy, while many of their performances occurred in private spaces, especially the symposium. I have suggested that ancient paratheatrical forms established a particularly close relationship between spectator and performer, using a variety of strategies (the absence of mask in the case of mime,

48 Pl. Leg. 658c.

49 Heron, Peri automatapoietikes 1. Cf. Murphy (1995). 
the close viewing space in the case of magic tricks and puppetry) to give spectators a feeling of intimacy with paratheatrical performance that standard theatrical genres lacked.

Writing on the concept of paratheatre in contemporary performance, including social performance, Wilshire suggests that 'the paratheatrical' challenges notions of fact and fiction, as it crosses from the fictional space of the stage to reality. ${ }^{50}$ This concept also applies to ancient paratheatre, as at the heart of the thauma associated with the thaumatopoioi was the ability to mix fiction and reality, as in the unmasked performance of mime, which represented the real, everyday world, or to make the impossible real, as in acrobatic feats, tricks of illusion, and the miraculous communication of myth through the silent gestures of pantomime dancers.

While I have attempted to define paratheatre as it might relate to the ancient theatre, there is an inherent instability in paratheatre, which make it difficult, and perhaps even counter-productive, to universalize. There are specific historical and cultural contexts which make a stronger distinction between theatre and paratheatre, and this delineation will not always be the same, or be made for the same reasons. For example, the theatre changed in Late Antiquity, to encompass primarily mime and pantomime..$^{51}$ In a consular diptych of Anastasius from $\mathrm{AD}$ 517, a group of mimes crowds on one side of the lower left register, and on the other side, a group of tragic actors, identified on the basis of their open-mouthed masks and high shoes. ${ }^{52}$ Is the distinction on this diptych, then, between theatre (tragedy) and paratheatre (mime), or merely two theatrical genres? And if mime, at this time, can be regarded simply as theatre, then what became of paratheatre? Rather than defining certain forms of performance as paratheatre across all time and space, it is important to recognize that what constitutes the theatre and what constitutes paratheatre varies depending on historical, cultural, and social context.

A word might be said, additionally, about the relationship between the term 'paratheatre' to 'paratragedy' and 'paracomedy,' terms which are suited to texts which respond to the literary tradition of tragedy and comedy. Lucian's Podagra, for example, is paratragic, in the sense that it responds to tragedy as a specific literary genre. ${ }^{53}$ Compare this to the Charition mime (P.Oxy. 413), which responds not just to the textual tradition of Euripidean drama but to its performance tradition, from which the audience was surely acquainted with

50 Wilshire (1990) 170.

51 For mime and pantomime in Late Antiquity, see Webb (2008).

52 Neiiendam (1992) 120, pl. 42.

53 Whitmarsh (2013) 176-185 discusses what he calls 'Lucianic Paratragedy'. 
the story. Moreover, mime is part of a performance tradition which, I have argued, is paratheatrical in its relationship to the theatre as a whole, not just to a specific genre within the theatre. The Charition is, therefore, both paratheatrical and also paratragic. Just as the use of 'paratheatre' to describe categories of performance such as mime, pantomime, trick magic, puppetry, and so on, follows the use of 'paratheatre' already in use in many areas of scholarship on theatre studies, including theatre history, so too this understanding of paratragedy and paracomedy as primarily textual and literary categories, which engage with specific literary genres, follows upon the current use of these terms in scholarship, where 'paratragedy' has been used to describe not only Lucian's satirical relationship to tragedy in the Podagra, but also allusions to tragedy in Plato, tragic parody in Old and Middle Comedy, and Plautus' literary engagements with tragic texts. ${ }^{54}$ The term paratheatre also may help in moving past modes of engagement with the dramatic tradition which privilege literary texts, such as allusion and intertext, to a broader conception of how performance traditions related to one another in Antiquity.

54 Plato: Trivingo (2009); Old and Middle Comedy: Farmer (2017) 67-116; Plautus: Manuwald (2014). Kanellakis (2017-2018) 63-64 reviews the use of 'paracomedy' in scholarship on the ancient theatre since 1993. 
